\title{
KEBIJAKAN PERLINDUNGAN HAK ASASI NARAPIDANA PADA LEMBAGA PEMASYARAKATAN DI DAERAH ISTIMEWA YOGYAKARTA*
}

\author{
Sri Hartini, ${ }^{* *}$ Anang Priyanto, ${ }^{* * *}$ dan Iffah Nurhayati****
}

Program Studi Pendidikan Kewarganegaraan, Fakultas Ilmu Sosial

Universitas Negeri Yogyakarta, Yogyakarta

Jalan Colombo Nomor 1, Sleman, D.I. Yogyakarta 55281

\begin{abstract}
The policy of human rights protection for prisoners in penitentiary DIY using combination method which are elite policy and rational policy. The application of elite policy is having correlation with prisoner's human rights protection, where as the type of rights, just followed what has been set in the legislation of policy. More over the policy changes as outlined in the legislation just a patchwork. As for rational policy method can be seen in the implementation of human rights compliance for prisoners, which is in real life required the creativity of penitentiary's officers considering humanity aspect.
\end{abstract}

Keywords: policy, human rights protection, prisoners.

\section{Intisari}

Kebijakan perlindungan hak asasi manusia terhadap narapidana di lingkungan lembaga pemasyarakatan se-DIY cenderung menggunakan model kebijakan elite. Hal ini bisa dilihat dari pemberian perlindungan hak narapidana yang hanya mengikuti apa yang telah diatur dalam kebijakan-kebijakan pusat. Selain itu, perubahan kebijakan yang dituangkan dalam peraturan perundangan hanya sekedar tambal sulam. Namun demikian, dalam pelaksanaan teknis pada kenyataannya mengharuskan kreativitas petugas lembaga pemasyarakatan sesuai dengan kebutuhan lapangan mengingat aspek kemanusiaan. Namun aspek kreativitas ini tetap mendasarkan pada peraturan yang ada. Dengan demikian terdapat juga sedikit unsur model kebijakan rasional dalam tahap pelaksanaan pemenuhan HAM narapidana.

Kata Kunci: kebijakan, perlindungan HAM, narapidana.

\section{Pokok Muatan}

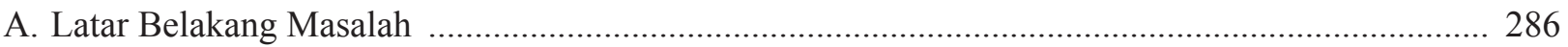

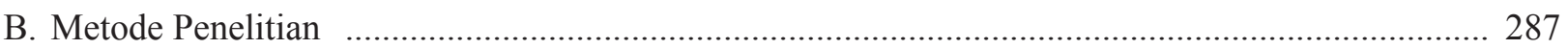

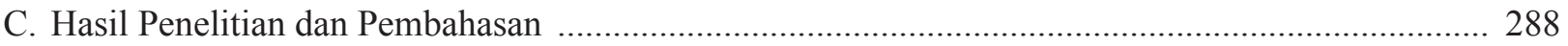

1. Karakteristik Narapidana pada Lembaga Pemasyarakatan di Daerah Istimewa Yogyakarta ...... 288

2. Kebijakan yang Terkait dengan Hak-Hak Asasi bagi Narapidana pada Lembaga Pemasyarakatan di Daerah Istimewa Yogyakarta

3. Penerapan Kebijakan Perlindungan Hak Asasi Manusia Narapidana pada Lembaga Pemasyarakatan di Daerah Istimewa Yogyakarta 290

D. Kesimpulan 298

\footnotetext{
Hasil penelitian desentralisasi Hibah Bersaing, Sumber Dana DIPA UNY 2014.

Alamat korespondensi: sri hartini@yahoo.co.id

*** Alamat korespondensi: anang_priyanto@yahoo.co.id

**** Alamat korespondensi: iffahnur@gmail.com
} 


\section{A. Latar Belakang Masalah}

Negara yang tidak menegakkan HAM di era globalisasi akan mengalami kesulitan ketika melakukan hubungan internasional. Globalisasi saat ini telah menyentuh segala aspek mulai dari kehidupan ekonomi, politik, sosial budaya, pertahanan keamanan, ilmu pengetahuan dan teknologi, pendidikan dan hukum. Globalisasi di bidang politik antara lain terasa dengan adanya isu tentang lingkungan hidup, transparansi, keterbukaan dan HAM. Globalisasi semakin memperkuat pemikiran-pemikiran untuk mengoperasionalkan nilai-nilai dasar HAM yang bersifat universal, invisible, interdependent and interrelated. ${ }^{1}$

Indonesia sejak menyatakan kemerdekaannya sudah peduli terhadap HAM. UUD 1945 yang dibuat sebelum Deklarasi Universal tentang HAM tahun 1948, sudah mencantumkan ketentuan-ketentuan yang berkaitan dengan HAM dalam pembukaan dan batang tubuhnya. Demikian juga dalam KRIS 1945 dan UUDS 1950. Kemudian ketika era Orde Baru, juga sudah berhasil dibuat pelbagai peraturan perundang-undangan yang berkaitan dengan pelaksanaan HAM. Lembaga yang dapat menjadi tumpuan dalam pelaksanaan HAM juga sudah dibentuk seperti KOMNAS HAM. Selanjutnya pada era reformasi telah diundangkan Undang-Undang Nomor 39 Tahun 1999 tentang Hak Asasi Manusia dan Undang-Undang Nomor 26 Tahun 2000 tentang Pengadilan HAM. Di samping itu hasil perubahan UUD 1945 memuat pasal-pasal mengenai HAM dalam Pasal 28A - Pasal 28J.

Berkaitan dengan masalah HAM di Indonesia tersebut dari dimensi hukum khususnya yang terkait dengan perlindungan HAM di bidang penegakan hukum masih bersifat diskriminatif, sehingga prinsip persamaan di muka hukum tidak terpenuhi, baik dari penyidikan, penuntutan dan peradilan sampai pada tingkat pembinaan di lembaga pemasyarakatan. ${ }^{2}$ Narapidana seperti halnya manusia yang memiliki hak-hak yang juga harus dilindungi oleh hukum. Hak-hak yang dilindungi tersebut terutama hak-hak yang sifatnya tidak dapat dilingkari dan diganggu gugat oleh siapa pun dalam keadaan apapun yakni HAM.

Berkaitan dengan perlindungan HAM terhadap narapidana di lembaga pemasyarakatan, sebenarnya sudah diatur dalam peraturan perundang-undangan. Hal ini ditegaskan dalam Pasal 14 ayat (1) Undang-Undang Nomor 12 Tahun 1995 tentang Pemasyarakatan bahwa narapidana berhak melakukan ibadah sesuai agama atau kepercayaannya, mendapat perawatan rohani maupun jasmani, mendapatkan pendidikan dan pengajaran, mendapatkan pelayanan kesehatan dan makanan yang layak, menyampaikan keluhan, mendapatkan bahan bacaan dan mengikuti siaran media massa lainnya yang tidak dilarang, mendapatkan upah dan premi atas pekerjaan yang dilakukan, menerima kunjungan keluarga, penasihat hukum atau orang lainnya, mendapatkan remisi dan asimilasi termasuk cuti menjelang bebas, dan hak-hak lain sesuai dengan peraturan perundangundangan yang berlaku. ${ }^{3}$ Kebebasan dasar manusia juga diatur dalam Pasal 9 - Pasal 66 UndangUndang Nomor 39 Tahun 1999 tentang Hak Asasi Manusia, yakni hak untuk hidup, ${ }^{4}$ hak untuk berkeluarga, ${ }^{5}$ hak untuk mengembangkan diri, ${ }^{6}$ hak untuk memperoleh keadilan, ${ }^{7}$ hak untuk kebebasan pribadi, ${ }^{8}$ hak atas rasa aman, ${ }^{9}$ hak turut serta dalam pemerintahan, ${ }^{10}$ hak atas kesejahteraan, ${ }^{11}$ hak

Muladi, 1997, Hak Asasi Manusia, Politik dan Sistem Peradilan Pidana, UNDIP, Semarang, hlm. 1.

Sri Hartini, "Perlindungan HAM dalam Praktek Ketatanegaraan”, Jurnal Civic, Vol. 2, No. 1, Juni 2005.

Pasal 14 ayat (1) Undang-Undang Nomor 12 Tahun 1995 tentang Pemasyarakatan (Lembaran Negara Republik Indonesia Tahun 1995 Nomor 77, Tambahan Lembaran Negara Republik Indonesia Nomor 3614).

Pasal 4 Undang-Undang Nomor 39 Tahun 1999 tentang Hak Asasi Manusia (Lembaran Negara Republik Indonesia Tahun 1999 Nomor 165). Pasal 10 Undang-Undang Nomor 39 Tahun 1999 tentang Hak Asasi Manusia (Lembaran Negara Republik Indonesia Tahun 1999 Nomor 165). Pasal 11 Undang-Undang Nomor 39 Tahun 1999 tentang Hak Asasi Manusia (Lembaran Negara Republik Indonesia Tahun 1999 Nomor 165). Pasal 17 Undang-Undang Nomor 39 Tahun 1999 tentang Hak Asasi Manusia (Lembaran Negara Republik Indonesia Tahun 1999 Nomor 165). Pasal 20 Undang-Undang Nomor 39 Tahun 1999 tentang Hak Asasi Manusia (Lembaran Negara Republik Indonesia Tahun 1999 Nomor 165). Pasal 28 Undang-Undang Nomor 39 Tahun 1999 tentang Hak Asasi Manusia (Lembaran Negara Republik Indonesia Tahun 1999 Nomor 165). Pasal 43 Undang-Undang Nomor 39 Tahun 1999 tentang Hak Asasi Manusia (Lembaran Negara Republik Indonesia Tahun 1999 Nomor 165). Pasal 36 Undang-Undang Nomor 39 Tahun 1999 tentang Hak Asasi Manusia (Lembaran Negara Republik Indonesia Tahun 1999 Nomor 165). 
wanita, ${ }^{12}$ dan hak anak. ${ }^{13}$ Namun, dalam kenyataan perlindungan HAM terhadap narapidana di lembaga pemasyarakatan belum terpenuhi secara maksimal. Menurut pemberitaan di media massa masih sering terjadi tindak kekerasan terhadap narapidana dan pungutan liar di Lembaga Pemasyarakatan Kelas IA Lowokwaru Malang. Hal ini sebagaimana yang dikemukakan oleh mantan narapidana Lowokwaru, mengaku mendapat penyiksaan saat di lembaga pemasyarakatan. $^{14}$

Berita Metrotvnews tanggal 15 Maret 2013, ratusan anggota salah satu kelompok Ormas berunjuk rasa di Lembaga Pemasyarakatan Salemba Jakarta Pusat yang terkait penyerangan kelompok narapidana kasus penyerangan di RSPAD terhadap narapidana kasus terorisme di Lembaga Pemasyarakatan Salemba. ${ }^{15}$ Kasus aktual juga terjadi di Lembaga Pemasyarakatan Cebongan Sleman DIY, sebagaimana dikemukakan Siti Noor Laila dari Komnas HAM kepada Rakyat Merdeka bahwa, "Ada indikasi pelanggaran HAM dalam kasus pembunuhan atas 4 (empat) tahanan penghuni Sub Anggrek 5 di Cebongan yang dilakukan oleh 11 (sebelas) anggota Kopassus. Indikasi pelanggaran HAM tersebut adalah pelanggaran atas hak hidup seseorang, hak atas rasa aman, hak perlindungan harta kekayaan, harta benda, nyawanya, serta hak bebas dari penganiayaan". ${ }^{16}$

Banyaknya kasus pelanggaran HAM terhadap narapidana menunjukkan lemahnya kebijakan operasional dalam perlindungan HAM narapidana. Kelemahan kebijakan operasional dapat disebabkan oleh banyak hal antara lain tidak jelasnya rumusan kebijakan yang ada, kurang tepatnya model kebijakan yang ditetapkan dalam kondisi, ruang dan waktu tertentu, political will pejabat pengambil kebijakan untuk membuat kebijakan perlindungan terhadap narapidana. Adanya kepentingan politik yang mewarnai kebijakan perlindungan HAM terhadap narapidana, dan kurangnya sarana dan prasarana bagi pelaksanaan kebijakan perlindungan HAM terhadap narapidana. Berbagai kelemahan sebagai asumsi lemahnya kebijakan operasional dalam perlindungan HAM narapidana tersebut menjadi fokus penelitian untuk pembuktian di lapangan. Dengan pembuktian di lapangan melalui penelitian dapat diperoleh sebuah model kebijakan perlindungan HAM Narapidana yang tepat dan berhasil guna.

Berdasarkan latar belakang masalah di atas, maka dapat dirumuskan permasalahan penelitian yaitu: Pertama, bagaimana kebijakan perlindungan HAM terhadap narapidana pada lembaga pemasyarakatan di DIY? Kedua, bagaimana model kebijakan yang diterapkan dalam perlindungan HAM terhadap narapidana di lembaga pemasyarakatan di DIY?

\section{B. Metode Penelitian}

Penelitian ini bertujuan untuk mengetahui kebijakan perlindungan HAM terhadap narapidana di lembaga pemasyarakatan se-DIY dan model kebijakan yang tepat diterapkan bagi perlindungan HAM terhadap narapidana di lembaga pemasyarakatan se-DIY. Penelitian ini termasuk penelitian deskriptif dengan pendekatan metode penelitian kualitatif. Penentuan subjek penelitian secara purposive. Subjek penelitian ini yaitu: Kepala Divisi Pemasyarakatan Kantor Wilayah Kementerian Hukum dan HAM Daerah Istimewa Yogyakarta, Kepala Lembaga Pemasyarakatan Kelas IIA Yogyakarta, Kelas IIB Sleman dan Kepala Lembaga Pemasyarakatan Narkotika Kelas IIA Yogyakarta, Kepala Seksi Pembinaan Pemasyarakatan Lapas Kelas IIA Yogyakarta, Kelas IIB Sleman dan Lembaga Pemasyarakatan

\footnotetext{
Pasal 45 Undang-Undang Nomor 39 Tahun 1999 tentang Hak Asasi Manusia (Lembaran Negara Republik Indonesia Tahun 1999 Nomor 165). Pasal 52 Undang-Undang Nomor 39 Tahun 1999 tentang Hak Asasi Manusia (Lembaran Negara Republik Indonesia Tahun 1999 Nomor 165). Ahmat Syaiful Afandi, "Mantan Napi Lowokwaru Mengaku Mendapat Penyiksaan Saat di Lapas", http://mediacenter.malangkota.go.id/ taykekerasan-pd-napi/8/6-2011, diakses 26 April 2013

15 Andri Yudhistira, "Napi Kasus Terorisme Dianiaya, Ormas Datangi LP Salemba", http://microsite.metrotvnews.com/metronews/ video/2013/03/15/6/173270/Napi-Kasus-Terorisme-Dianiaya-Ormas-Datangi-LP-Salemba, diakses 26 April 2013.

16 Dani Prabowo, "Komnas HAM: Ada indikasi Pelanggaran HAM dalam Kasus Cebongan", http://rmol.co/read/2013/04/16/106576/Siti-NoorLaila:-Ada-Pelanggaran-HAM-Dalam-Kasus-Cebongan-, diakses 26 April 2013.
} 
Narkotika beserta para stafnya; narapidana di Lembaga Pemasyarakatan Kelas IIA Yogyakarta dalam kasus Pidana Umum (wanita dan laki-laki) dan narapidana dalam kasus korupsi, narapidana di Lembaga Pemasyarakatan Kelas IIB Lembaga Pemasyarakatan dalam kasus Pidana Umum dan narapidana di Lembaga Pemasyarakatan Narkotika Kelas IIA Yogyakarta. Data diperoleh melalui wawancara, observasi dan dokumentasi di perkuat dengan Focus Group Discussion (FGD). Keabsahan data dengan triangulasi. Analisis data secara induktif melalui reduksi data, unitisasi dan kategorisasi data, display data dan kesimpulan/verifikasi. Analisis induktif digunakan untuk menilai dan menganalisis data yang sudah difokuskan tentang kebijakan perlindungan HAM terhadap narapidana di lembaga pemasyarakatan se-DIY.

\section{Hasil Penelitian dan Pembahasan}

1. Karakteristik Narapidana pada Lembaga Pemasyarakatan di Daerah Istimewa Yogyakarta

Narapidana dari Lembaga Pemasyarakatan Kelas IIA Yogyakarta (Wirogunan) dan Lembaga Pemasyarakatan Kelas IIB Sleman (Cebongan) umumnya merupakan pelaku dari tindak pidana umum. Namun di Lembaga Pemasyarakatan Kelas IIA Yogyakarta terdapat juga narapidana tindak pidana khusus yakni tindak pidana korupsi dan tindak pidana narkotika, khusus bagi pelaku wanita dan anak-anak. Sedangkan bagi pria pelaku tindak pidana narkotika, ditempatkan di Lembaga Pemasyarakatan Narkotika Kelas IIA Yogyakarta. Berdasarkan data dari Ditjen Pemasyarakatan Kementerian Hukum dan HAM Indonesia, jumlah narapidana di Lembaga Pemasyarakatan Yogyakarta pada Tanggal 22 Agustus 2014 yakni 409 (empat ratus sembilan) orang terdiri dari pelaku tindak pidana umum sejumlah 370 orang dan narapidana tindak pidana korupsi sejumlah 39 (tiga puluh sembilan) orang. ${ }^{17}$
Berkaitan dengan kapasitas tempat hunian Narapidana, di Lembaga Pemasyarakatan Kelas IIA Yogyakarta dan Lembaga Pemasyarakatan Narkotika Kelas IIA Yogyakarta tidak mengalami kelebihan kapasitas untuk hunian narapidana lakilaki, sedangkan untuk hunian narapidana wanita di Lembaga Pemasyarakatan Kelas IIA Yogyakarta melebihi kapasitas. Hal ini terlihat pada tanggal 28 Agustus 2014 di Blok A tempat hunian seluas $20 \mathrm{~m}^{2}(5 \mathrm{~m} \times 4 \mathrm{~m})$ dihuni oleh 40 napi Wanita dan seorang bayi, yang seharusnya kapasitasnya hanya dihuni oleh 14 (empat belas) narapidana. Demikian juga di Lembaga Pemasyarakatan Kelas IIB Sleman mengalami kelebihan kapasitas, terlihat pada tanggal 28 Agustus 2014 ketika peneliti melakukan observasi di Lembaga Pemasyarakatan Sleman, kapasitas tempat hunian yang ideal atau normal ditempati sejumlah 163 Napi tetapi ditempati oleh 360 (tiga ratus enam puluh) narapidana. Setiap blok rata-rata melebihi kapasitas tempat hunian yang seharusnya. Misalnya Blok E1 yang seharusnya 6 (enam) orang narapidana diisi 10 (sepuluh) narapidana E2 seharusnya 3 (tiga) narapidana, diisi 6 (enam) narapidana dan Blok E3 yang seharusnya 3 (tiga) narapidana, diisi 9 (sembilan) narapidana.

\section{Kebijakan yang terkait dengan Hak-Hak Asasi Bagi Narapidana pada Lembaga Pemasyarakatan di Daerah Istimewa Yogyakarta}

Perlindungan HAM bagi Narapidana menjadi salah satu sasaran kebijakan Kementerian Hukum dan HAM yang dituangkan dalam berbagai bentuk peraturan perundang-undangan. Kebijakan inilah yang kemudian dilaksanakan oleh Unit Pelaksana Teknis Lembaga Pemasyarakatan di seluruh Indonesia, termasuk Lapas yang ada di DIY. Dari wawancara dengan pihak Kantor Wilayah Kementerian Hukum dan HAM, Kepala Lembaga Pemasyarakatan dan Kepala Seksi Pembinaan Pemasyarakatan di Lembaga Pemasyarakatan se-DIY, macam hak narapidana yang dipenuhi 
di lembaga pemasyarakatan hanya mengikuti apa yang telah diatur dalam kebijakan-kebijakan pusat, artinya pihak lembaga pemasyarakatan tidak mengupayakan adanya hak-hak yang lain. Yang kemudian menjadikan berbeda adalah pada pelaksanaan atau pemenuhannya karena beberapa faktor yang akan dijelaskan pada bagian selanjutnya. Mengenai kebijakan yang dimaksud meliputi: (1) Undang-Undang, seperti Undang-Undang Nomor 12 Tahun 1995 tentang Pemasyarakatan; (2) Peraturan Pemerintah, meliputi Peraturan Pemerintah Nomor 31 Tahun 1999 tentang Pembinaan dan Pembimbingan Warga Binaan Pemasyarakatan. Kemudian dikeluarkan juga Peraturan Pemerintah Nomor 32 Tahun 1999 tentang Syarat dan Tata Cara Pelaksanaan Hak Warga Binaan Pemasyarakatan sebagaimana diubah dengan Peraturan Pemerintah Nomor 28 Tahun 2006 tentang Perubahan Atas Peraturan Pemerintah Nomor 32 Tahun 1999 tentang Syarat dan Tata cara Pelaksanaan Hak Warga Binaan Pemasyarakatan dan Peraturan Pemerintah Nomor 99 Tahun 2012 tentang Perubahan Kedua Atas Peraturan Pemerintah Nomor 32 Tahun 1999 tentang Syarat dan Tata cara Pelaksanaan Hak Warga Binaan Pemasyarakatan. Selain itu, terdapat Peraturan Pemerintah Nomor 58 Tahun 1999 tentang SyaratSyarat dan Tata Cara Pelaksanaan Wewenang, Tugas dan Tanggung Jawab Perawatan Tahanan; (3) Keputusan Presiden Nomor 174 Tahun 1999 tentang Remisi; (4) Peraturan Menteri Hukum dan Hak Asasi Manusia Nomor M.01.PK.04.10 Tahun 2007 tentang Syarat dan Tata Cara Pelaksanaan Asimilasi, Pembebasan Bersyarat, Cuti Menjelang Bebas dan Cuti Bersyarat, sebagaimana diubah dengan Peraturan Menteri Hukum dan Hak Asasi Manusia Nomor M.HH.01.PK.05.06 tahun 2008 tentang Perubahan Atas Peraturan Menteri Hukum dan Hak Asasi Manusia Nomor M.01.PK.04.10 Tahun 2007 tentang Syarat dan Tata Cara Pelaksanaan Asimilasi, Pembebasan Bersyarat, Cuti Menjelang Bebas dan Cuti Bersyarat dan diubah lagi dengan Peraturan Menteri Hukum dan Hak Asasi Manusia Nomor M.HH-02.PK.05.06 tahun 2007 tentang Perubahan
Kedua Atas Peraturan Menteri Hukum dan Hak Asasi Manusia Nomor M.01.PK.04.10 tahun 2007 tentang Syarat dan Tata Cara Pelaksanaan Asimilasi, Pembebasan Bersyarat, Cuti Menjelang Bebas, dan Cuti Bersyarat; (5) Surat Edaran Menteri Hukum dan HAM Nomor M.HH.04.PK.01.05.04 Tahun 2012 tentang Pelaksanaan Peraturan Pemerintah Nomor 99 Tahun 2012 tentang Perubahan Kedua Atas Peraturan Pemerintah Nomor 32 Tahun 1999 tentang Syarat dan Tata Cara Pelaksanaan Hak Warga Binaan Pemasyarakatan. Kemudian Surat Edaran Menteri Hukum dan HAM Nomor M.HH04.PK.01.05.06 Tahun 2013 tentang Petunjuk Pelaksanaan Pemberlakuan Peraturan Pemerintah Nomor 99 Tahun 2012 tentang Syarat dan Tata Cara Pelaksanaan Hak Warga Binaan Pemasyarakatan. Selanjutnya Surat Edaran Menteri Hukum dan HAM Nomor M.HH-13.PK.01.05.06 Tahun 2014 tentang Pelaksanaan Peraturan Pemerintah Nomor 99 Tahun 2012 tentang Perubahan Kedua Atas Peraturan Pemerintah Nomor 32 Tahun 1999 tentang Syarat dan Tata Cara Pelaksanaan Hak Warga Binaan Pemasyarakatan; (6) Surat Direktorat Jenderal Pemasyarakatan Nomor PAS.PK.01.01.02.162 Tahun 2013 tentang Perihal Petunjuk Pelaksanaan Surat Edaran Menteri Hukum dan HAM Nomor M.HH-04.PK.01.05.06 Tahun 2013. Surat Direktorat Jenderal Pemasyarakatan Nomor PAS. PK.01.05.06.124 Tahun 2013 Perihal Crash Program dalam rangka pengendalian hunian; (7) Surat Kepala Kantor Wilayah Kementerian Hukum dan HAM DIY Nomor W14.PK.01.05.06.3043 tanggal 15 Juli 2013 perihal Petunjuk Pelaksanaan Pemberlakuan Peraturan Pemerintah Nomor 99 Tahun 2012; serta (8) Peraturan Bersama Ketua Mahkamah Agung, Menteri Hukum dan HAM, Menteri Kesehatan, Menteri Sosial, Jaksa Agung, Kepala Kepolisian Negara, dan Kepala Badan Narkotika Nasional Nomor 01/PB/MA/III/2014; Nomor 03 Tahun 2014; Nomor 11 Tahun 2014; Nomor 03 Tahun 2014; Nomor PER-005/A/ JA/03/2014; Nomor 1 Tahun 2014; Nomor PERBER/01/III/2014/BNN tentang Penanganan Pecandu Narkotika dan Korban Penyalahgunaan 
Narkotika ke Dalam Lembaga Rehabilitasi.

Berdasarkan uraian tersebut di atas menunjukkan bahwa model kebijakan perlindungan HAM terhadap Narapidana di Lembaga Pemasyarakatan se-DIY yang diterapkan termasuk model kebijakan elite. Model ini menekankan pada kebijakan yang dibuat oleh para elite politik. Kebijakan publik boleh dikatakan identik dengan perspektif elite politik. Kebijakan negara mencerminkan kehendak atau nilai-nilai sekelompok kecil orang yang berkuasa. Nilai-nilai, sikap dan pandangan elite sangat mempengaruhi kebijakan yang dihasilkan, namun tidaklah berarti kebijakan-kebijakan yang dibuat oleh para elite politik selalu tidak mementingkan kesejahteraan rakyat. Jika terjadi perubahan-perubahan kebijakan biasanya sifatnya tambal sulam ataupun trial-error yang hanya mengubah atau memperbaiki kebijakankebijakan sebelumnya. Dalam kondisi tertentu para elite politik tetap membutuhkan dukungan massa, sehingga mereka juga harus memuaskan sebagian massa tersebut dan tanggung jawab untuk menyejahterakan masyarakat dianggap tetap terletak di tangan para elite politik. ${ }^{18}$

3. Penerapan Kebijakan Perlindungan Hak Asasi Manusia Narapidana pada Lembaga Pemasyarakatan di Daerah Istimewa Yogyakarta

a. Hak-Hak Narapidana yang Telah Dipenuhi/Dilindungi

Mengenai hak-hak Narapidana yang dilindungi, dalam praktek, sama dengan yang telah diatur dalam kebijakan, yakni meliputi:

1) Hak untuk Beribadah Sesuai dengan Agama dan Kepercayaannya

Fasilitas yang disediakan dalam rangka pemenuhan hak beribadah dari ketiga Lembaga Pemasyarakatan di Yogyakarta yaitu disediakannya tempat khusus peribadatan masjid dan gereja/kapel. Pura juga tersedia di Lapas Kelas IIA Yogyakarta. Waktu penggunaan tempat ibadah dibatasi karena lokasi tempat ibadah di luar blok ruangan para narapidana. Misalnya bagi yang beragama Islam sholat lima waktu lebih banyak dilakukan dalam ruang sel, terkait dengan waktu "bukaan blok" yang hanya pada pagi hari. Masjid digunakan sholat Jum'at, untuk belajar membaca Al-Qur'an dengan metode Iqra' (setiap pagi di hari Senin sampai dengan Sabtu) yang dilanjutkan dengan ceramah singkat. Selain itu seminggu 2 (dua) kali diadakan pengajian interaktif. Kegiatan ini dilakukan oleh semua lembaga permasyarakatan di Yogyakarta. Bagi yang beragama Kristen Protestan ataupun Katolik, peribadatan di gereja/ kapel diselenggarakan 4 (empat) kali seminggu. Berkaitan dengan kebebasan menjalankan ibadah sesuai dengan keyakinan, pada bulan Ramadhan pihak lembaga pemasyarakatan memberikan kebebasan mengenai waktu dimulainya puasa Ramadhan. Dalam hal ini lembaga pemasyarakatan menyediakan makanan sahur bagi warga binaan yang memulai puasa lebih awal dari yang lain. Semua lembaga pemasyarakatan di Yogyakarta memberikan perlakuan yang sama dalam masalah ini. Pihak lembaga pemasyarakatan tidak akan mengambil resiko jika tidak menyerap aspirasi warga binaan, apalagi terkait dengan keyakinan dalam menjalankan ibadah.

2) Hak Mendapat Perawatan Baik Jasmani Maupun Rohani/ Pembinaan Kepribadian

Narapidana juga mempunyai hak untuk mendapatkan perawatan jasmani berupa kesempatan berolahraga dan

18 Samodra Wibawa, 1994, Kebijakan Publik Proses dan Analisis, Intermedia, Jakarta, hlm. 9. 
rekreasi, perlengkapan pakaian, serta seragam bagi narapidana dan anak pidana setelah selesai didaftar. Selain itu, narapidana dan anak pidana juga mendapatkan perlengkapan tidur dan mandi yang telah selesai didaftar. Lembaga pemasyarakatan di Daerah Istimewa Yogyakarta secara seragam menyelenggarakan kegiatan olahraga di hari Jum'at pagi dengan senam dan kebanyakan melakukan game bola volley antar napi ataupun dengan petugas lembaga pemasyarakatan. Kegiatan ini bisa terselenggara dengan rutin dan diikuti oleh sebagian warga binaan. Namun di Lembaga Pemasyarakatan Narkotika Yogyakarta, kegiatan semacam ini juga kurang diminati oleh warga binaan. Hal ini disinyalir karena warga Lembaga Pemasyarakatan narkotika mempunyai karakteristik yang cenderung "malas" akibat pengaruh penyalahgunaan narkotika. Petugas Lembaga Pemasyarakatan juga tidak dapat memaksa karena itu merupakan hak warga binaan. Mengenai baju seragam dan perlengkapan tidur, narapidana juga sudah mendapatkan dengan kualitas standar. Untuk perlengkapan mandi, narapidana mendapatkan dari lembaga pemasyarakatan pada saat pertama kali masuk. Selanjutnya narapidana mengusahakan sendiri dari uang pribadi yang dititipkan ke Lembaga Pemasyarakatan dan diberikan kepada narapidana dalam bentuk voucher untuk berbelanja ke koperasi lembaga pemasyarakatan. Narapidana dilarang membawa uang "cash" karena adanya uang cash berpotensi menimbulkan masalah di dalam lingkungan lembaga pemasyarakatan.
Seharusnya perlengkapan mandi, sebagai "hak", disediakan oleh lembaga pemasyarakatan secara cumacuma. Namun kebijakan anggaran dari kementerian tidak mengalokasikan untuk hal tersebut. Fasilitas tempat untuk mandi di ruang sel narapidana semua lembaga pemasyarakatan juga masih belum memadai, karena tembok pembatas tempat mandi/WC dengan ruangan hanya setinggi 1 meter, sehingga apabila ruang dihuni lebih dari satu orang menjadi semakin tidak nyaman. Namun model dan tata letak seperti itu sudah merupakan model baku yang ditetapkan oleh Pemerintah Pusat. Alasan yang dikemukakan yaitu adanya kekhawatiran apabila tempat mandi atau WC dipisahkan dari ruang sel atau dibatasi tembok tinggi atau diberi pintu, penghuni yang menggunakan fasilitas tersebut akan melakukan hal-hal yang tidak diinginkan, seperti bunuh diri atau halhal lain yang membahayakan.

Selain perawatan jasmani, narapidana juga mempunyai hak atas perawatan rohani. Perawatan rohani yang dimaksud meliputi bimbingan rohani dan pendidikan budi pekerti sebagaimana yang tercantum dalam Pasal 6 ayat (1) Peraturan Pemerintah Nomor 32 Tahun 1999 tentang Syarat dan Tata Cara Pelaksanaan Hak Warga Binaan Pemasyarakatan. Dalam peraturan tersebut tidak dijelaskan lebih lanjut apa yang dimaksud dengan bimbingan rohani karena dalam penjelasan disebutkan "sudah jelas". Dalam praktek, bimbingan kerohanian ditafsirkan sebagai bimbingan kegiatan keagamaan yang dilakukan antara pihak Lembaga Pemasyarakatan bekerja sama 
dengan kantor Kementerian Agama setempat dan dari perkumpulanperkumpulan keagamaan. Hal ini dimungkinkan dengan dasar Pasal 5 Peraturan Pemerintah a quo yang isinya membolehkan lembaga pemasyarakatan untuk bekerja sama dengan instansi pemerintah terkait, badan-badan kemasyarakatan lainnya atau perorangan yang kegiatannya sesuai dengan penyelenggaraan sistem pemasyarakatan.

3) Hak Mendapatkan Pendidikan dan Pengajaran

Memperoleh pendidikan dan pengajaran merupakan hak konstitusional semua warga negara, tak terkecuali narapidana. Meskipun kebebasannya dibatasi, namun mereka tetap berhak atas pendidikan dan pengajaran. Lembaga pemasyarakatan yang ada di Daerah Istimewa Yogyakarta menyediakan layanan pendidikan kelompok Belajar Paket $\mathrm{A}, \mathrm{B}$, dan $\mathrm{C}$ bagi mereka yang belum menyelesaikanpendidikanpadajenjang SD (untuk paket A), SMP (untuk paket B) dan SMA (untuk paket C). Sebagai pamong belajarnya berasal dari Dinas Pendidikan setempat, sementara petugas lembaga pemasyarakatan mengatur pelaksanaannya saja.

4) Hak Mendapatkan Pelayanan Kesehatan dan Makanan yang Layak

Kesehatan termasuk masalah krusial di lingkungan Lembaga Pemasyarakatan. Prakteknya disediakan tempat pemeriksaan kesehatan berikut dokter dan paramedis. Namun kendalanya adalah masih terbatas sarana dan prasarana yang menunjang perlindungan para narapidana atas kesehatan yang diperolehnya. Ber- kaitan dengan penyediaan makanan yang layak, secara seragam di lembaga pemasyarakatan se-Daerah Istimewa Yogyakarta diberikan 3 (tiga) kali sehari, meskipun menunya kurang bervariasi.

\section{5) Hak Menyampaikan Keluhan}

Hak menyampaikan keluhan dari narapidana dilakukan melalui Wali Pemasyarakatan. Penyampaian tersebut dalam bentuk tertulis melalui kotak surat yang tersedia di masingmasing lembaga pemasyarakatan. Keluhan tersebut terkait dengan narapidana yang mengalami hambatan baik dalam berinteraksi dengan sesama penghuni dan petugas maupun dalam mengikuti program pembinaan. Dalam kenyataan untuk menyampaikan keluhan kurang mendapatkan perhatian atau belum sesuai yang diharapkan oleh narapidana.

6) Hak Mendapatkan Bahan Bacaan dan Mengikuti Siaran Media Massa Lainnya yang Tidak Dilarang

Perpustakaan selalu ada di setiap lembaga pemasyarakatan, hanya saja bacaan yang tersedia terbatas sekali. Demikian juga untuk mengikuti informasi yang terkait dengan peristiwa yang terjadi baik dalam negeri maupun luar negeri bisa melalui televisi yang tersedia di setiap lembaga pemasyarakatan. Namun para narapidana tidak mempunyai kebebasan untuk melihat atau mendengarkan semua peristiwa karena selalu dipantau oleh petugas melalui CCTV. Apabila terkait dengan tindak kekerasan, apalagi kekerasan yang terjadi di suatu lembaga pemasyarakatan misal kerusuhan atau pembakaran lembaga pemasyarakatan 
yang ditayangkan melalui media elektronik seperti televisi, maka televisi akan dimatikan oleh petugas.

7) Hak Menerima Kunjungan Keluarga, Penasehat Hukum atau Orang Tertentu Lainnya

Untuk menerima kunjungan keluarga baik di Lembaga Pemasyarakatan Yogyakarta dan Sleman, disediakan tempat kunjungan dengan waktunya terjadwal dua kali setiap pekan yakni hari Selasa dan Kamis selama 20 (dua puluh) menit. Dalam kesempatan tersebut bisa digunakan untuk bertemu dan berkomunikasi dengan keluarga dan dari pihak keluarga diperbolehkan membawakan makanan yang terlebih dahulu diperiksa oleh petugas. Hal ini berbeda dengan di Lembaga Pemasyarakatan Narkotika Kelas IIA Yogyakarta. Di lembaga pemasyarakatan tersebut kunjungan keluarga tidak bisa secara bebas sebab hanya bisa berkomunikasi dengan diberi pembatas kaca dan tidak diperbolehkan membawa makanan untuk narapidana. Apabila narapidana menginginkan makanan di luar jatah dari Lembaga Pemasyarakatan bisa membeli makanan yang disediakan pihak lembaga pemasyarakatan dengan voucher atas nama masingmasing narapidana.

\section{8) Hak Mendapatkan Remisi}

Hak untuk mendapat remisi setiap tahun diberikan dua kali yakni remisi umum diberikan setiap tanggal 17 Agustus dan remisi khusus setiap hari raya sesuai agama yang dipeluk masing-masing narapidana. Berdasarkan data yang ada, jumlah penghuni di Lembaga Pemasyarakatan Yogyakarta pada tanggal 28 Juli 2014 sejumlah 380 (tiga ratus delapan puluh) orang terdiri dari 399 (tiga ratus sembilan puluh sembilan) tahanan negara dan 341 (tiga ratus empat puluh satu) narapidana. Mereka memperoleh remisi sebanyak 228 (dua ratus dua puluh delapan) warga binaan lembaga pemasyarakatan. Banyaknya remisi bervariasi tergantung lama masa pidana penjara. Remisi terendah sebanyak 15 (lima belas) hari, dan yang terbesar sebanyak 2 (dua) bulan. Akibat dari remisi ini, 6 (enam) orang narapidana saat itu juga dapat menghirup udara bebas. Nampak beberapa diantaranya mereka dijemput oleh anggota keluarga dengan rasa senang. Remisi juga diberikan pihak Lembaga Pemasyarakatan Kelas IIB Sleman sejumlah 158 (seratus lima puluh delapan) orang dari 268 (dua ratus enam puluh delapan) orang narapidana dengan kapasitas 163 (seratus enam puluh delapan) orang. Untuk narapidana Narkotika Kelas IIA Yogyakarta remisi khusus hari pada bulan Juli tahun 2014 (hari raya Idul Fitri) diberikan kepada narapidana dengan pidana di atas 5 (lima) tahun sejumlah 35 (tiga puluh lima) narapidana yaitu 1 (satu) bulan. Bagi narapidana yang dipidana di bawah 5 (lima) tahun diberikan kepada 88 (delapan puluh delapan) narapidana yaitu antara 15 (lima belas) hari sampai 1 (satu) bulan, sedang pada HUT ke69 Remisi juga diberikan kepada 148 (seratus empat puluh delapan) narapidana dari 201 (dua ratus satu) narapidana dengan kapasitas 474 (empat ratus tujuh puluh empat) orang. Namun bagi narapidana karena melakukan tindak pidana korupsi dan narkotika pemberian remisi belum terwujud. Hal ini menunjukkan adanya 
diskriminasi dalam pemberian remisi.

\section{9) Hak Asimilasi}

Hak para narapidana untuk memperoleh asimilasi meskipun sudah terlindungi, namun tidak digunakan oleh narapidana. Kendala dari asimilasi adalah narapidana merasa malu karena persyaratan harus diketahui oleh aparat desa/kades/lurah setempat, sehingga narapidana tidak memanfaatkan haknya untuk memperoleh asimilasi tersebut.

10) Hak untuk Mendapatkan Pembebasan Bersyarat, Cuti Bersyarat, Cuti Menjelang Bebas

Narapidana karena tindak pidana umum di lembaga pemasyarakatan seDaerah Istimewa Yogyakarta berhak untuk mendapat hak pembebasan bersyarat, cuti mengunjungi keluarga, dan cuti menjelang bebas. Hal ini sudah dipenuhi sesuai dengan Peraturan Pemerintah Nomor 28 Tahun 2006, namun demikian khusus untuk cuti mengunjungi keluarga tidak diberikan kepada narapidana tindak pidana korupsi dan narkotika.

11) Hak Lain yang Sesuai dengan Peraturan Perundang-Undangan (Hak Memilih pada Saat Pemilihan Umum)

Narapidana baik di Lembaga Pemasyarakatan Yogyakarta, Sleman maupun Lembaga Pemasyarakatan Narkotika tidak ketinggalan memberikan hak suaranya baik dalam Pemilu Legislatif (Pileg) pada tanggal 9 April 2014 maupun dalam Pemilu Presiden/Wakil Presiden (Pilpres) pada tanggal 9 Juli 2014 yang sudah terlaksana. Di Lembaga Pemasyarakatan Yogyakarta dalam Pileg dari 339 (tiga ratus tiga puluh sembilan) narapidana, sebanyak 322 (tiga ratus dua puluh dua) yang memberikan hak suaranya. Tujuh orang napi tidak mendapat hak suara, karena 4 (empat) orang WNA dan 3 (tiga) lainnya adalah anak-anak. Kemudian dalam Pilpres dilaksanakan di TPS XI Kl Gunung Ketur Kecamatan Pakualaman merupakan TPS Khusus, karena terdapat di Lembaga Pemasyarakatan Wirogunan sebanyak 369 (tiga puluh enam puluh sembilan) orang pemilih melaksanakan pencoblosan Pilpres pada hari Rabu 9 Juli 2014 terdiri dari 280 (dua ratus delapan puluh) Warga Binaan Permasyarakatan (WBP) laki-laki, 84 (delapan puluh empat) WBP wanita, 1 (satu) orang petugas lembaga pemasyarakatan, 1 (satu) orang petugas rumah tahanan, 1 (satu) orang istri pegawai dan 1 (satu) orang panitia TPS.

b. Hak-Hak Narapidana yang Belum Terlindungi atau Belum Dirasakan oleh Narapidana

1) Biaya Perawatan Kesehatan Narapidana

Narapidana yang dirawat di rumah sakit, biaya perawatan dibebankan kepada negara, namun dalam praktek ditanggung oleh narapidana atau keluarganya. Demikian juga biaya untuk rehabilitasi bagi pengguna narkotika di Lembaga Pemasyarakatan Narkotika Kelas IIA Yogyakarta juga ditanggung oleh yang bersangkutan atau keluarganya.

2) Hak Mendapatkan Kenyamanan Tempat Hunian Para Narapidana di Lembaga Pemasyarakatan

Hak mendapatkan kenyamanan tempat hunian para narapidana di 
Lembaga Pemasyarakatan Kelas IIA Yogyakarta khususnya narapidana wanita belum dirasakan, karena tempat hunian melebihi kapasitas. Hal ini terlihat dari Blog Hunian Narapidana Wanita, kapasitas 14 (empat belas) orang dihuni oleh 40 (empat puluh) narapidana dan seorang bayi. Demikian juga narapidana di Lembaga Pemasyarakatan Kelas IIB Sleman juga mengalami kelebihan kapasitas hunian, yang seharusnya kapasitas hunian untuk 163 (seratus enam puluh tiga) orang tetapi dihuni oleh 268 (dua ratus enam puluh delapan) orang.

3) Hak untuk Mendapatkan Keterampilan atau Pelatihan

Negara bertanggung jawab penuh untuk memenuhi hak narapidana untuk mendapatkan keterampilan atau pelatihan, dengan harapan para narapidana setelah bebas akan mempunyai kemandirian secara ekonomi. Namun untuk tahun anggaran 2014 tidak ada, sehingga kegiatan pelatihan atau keterampilan belum terpenuhi. Meskipun dari sisi peralatan tersedia seperti bengkel las dan pembuatan spring bed, salon, laundry, penjahit, pertukangan kayu, pembuatan batako, perikanan dan pertanian serta prakarya, tetapi secara operasional tidak bisa terlaksana terutama di Lembaga Pemasyarakatan Narkotika Kelas IIA Yogyakarta dan Lembaga Pemasyarakatan Kelas IIB Sleman.

\section{4) Asimilasi}

Hak para Narapidana untuk memperoleh asimilasi di Lembaga Pemasyarakatan se-Daerah Istimewa Yogyakarta belum terwujud. Belum terwujudnya hak asimilasi ini, karena adanya persyaratan harus diketahui untuk ditandatangani kepala desa atau lurah dimana narapidana bertempat tinggal, sehingga ada perasaan malu dari narapidana sendiri berakibat belum diterimanya hak asimilasi tersebut.

\section{5) Remisi untuk Narapidana Kasus Korupsi}

Hak narapidana karena tindak pidana korupsi belum dirasakan oleh narapidana di Lembaga Pemasyarakatan Yogyakarta, karena diskriminasi persyaratan untuk memperoleh remisi.

6) Mendapatkan Upah atau

Premi atas Pekerjaan yang Dilakukan bagi Narapidana

Upah atau premi atas pekerjaan yang dilakukan oleh narapidana belum terpenuhi atau dirasakan baik narapidana laki-laki maupun narapidana wanita yang berada di Lembaga Pemasyarakatan Yogyakarta. Demikian juga Narapidana lakilaki yang berada di Lembaga Pemasyarakatan Kelas IIB Sleman maupun Lembaga Pemasyarakatan Narkotika Kelas IIA Yogyakarta.

c. Inventarisasi Permasalahan yang Berkaitan dengan Perlindungan HAM terhadap Narapidana di Lembaga Pemasyarakatan yang Perlu Dituangkan dalam Rumusan Kebijakan

1) Tidak tersedianya "Bilik Cinta" untuk Para Narapidana yang Sudah Menikah

Tersedianya "bilik cinta" merupakan salah satu pemenuhan HAM untuk membentuk keluarga dan melanjutkan keturunan melalui perkawinan yang sah. Dengan tidak tersedianya "bilik cinta" di lembaga pemasyarakatan bagi narapidana yang 
sudah menikah dapat dikategorikan sebagai bentuk pelanggaran HAM. Namun permasalahan yang muncul selalu berkait dengan persoalan moral, sikap mental dan etika seseorang yang telah berumah tangga. Tidak mudah bagi orang lain untuk percaya begitu saja jika narapidana didatangi orang lain yang mengaku kerabat atau keluarganya. Lebih-lebih bukti surat nikah yang ditunjukkan masih saja petugas curiga keaslian dari surat nikah tersebut. Bahkan dengan disediakannya "bilik cinta" dapat menimbulkan kesan lembaga pemasyarakatan sebagai tempat "lokalisasi pelacuran". Kesan inilah yang menyebabkan tidak dipenuhinya "bilik cinta" di Lembaga Pemasyarakatan. Persoalan "bilik cinta" ini memang perlu mendapat perhatian serius dari Pemerintah agar tidak terjadi kasus-kasus perilaku seks menyimpang di lembaga pemasyarakatan.

2) Tidak Tersedianya Anggaran Negara untuk Biaya Kesehatan Narapidana di Lembaga Pemasyarakatan Se-Daerah Istimewa Yogyakarta dan Tidak Tersedianya Alat-Alat Kesehatan

Permasalahan tidak tersedianya anggaran untuk kesehatan ternyata disebabkan oleh kebijakan Pemerintah mengenai pemotongan anggaran tahun 2014. Informasi yang disampaikan petugas lembaga pemasyarakatan menyatakan bahwa kebijakan pemotongan anggaran dimungkinkan adanya kegiatan politik Pilpres. Tidak tersedianya dana kesehatan merupakan bentuk pelanggaran HAM untuk memperoleh pelayanan kesehatan. Permasalahan yang muncul dari tidak tersedianya dana kesehatan sangat berkaitan dengan unsur kemanusiaan yang dirasakan oleh para petugas lembaga pemasyarakatan terutama pelayanan tugas yang ditujukan kepada narapidana yang sedang menderita sakit, terutama narapidana dari keluarga tidak mampu. Untuk mengatasi hal tersebut lembaga pemasyarakatan telah berusaha untuk menjalin kerjasama dengan Pemerintah Daerah dan Badan Penyelenggara Jaminan Sosial (BPJS) untuk dapat membantu biaya kesehatan kepada narapidana yang sakit, meskipun dana kesehatan yang diperoleh tidak begitu memadai namun setidak-tidaknya dapat meringankan beban Narapidana dan keluarganya.

3) Belum Adanya Kelanjutan dari Keterampilan yang Dapat Menciptakan Pekerjaan bagi Para Narapidana dari Pemerintah

Belum adanya kelanjutan dari keterampilan yang bisa menciptakan pekerjaan bagi para narapidana dari Pemerintah sehingga masih terjadi residivis yang berakibat over capacity di lembaga pemasyarakatan khususnya yang dijatuhi pidana umum yakni Lembaga Pemasyarakatan Kelas IIA Yogyakarta dan Lembaga Pemasyarakatan Kelas IIB Sleman.

Narapidana yang telah mendapat keterampilan, setelah bebas dari lembaga pemasyarakatan banyak yang tidak bisa menciptakan pekerjaan secara mandiri dan lebih senang menjadi pekerja, sehingga sulit untuk mendapatkan pekerjaan. Kebijakan pembinaan kepada narapidana harus disertai pemberian materi tentang kewirausahaankepadapara narapidana, 
sehingga memiliki jiwa mandiri yang kuat. Semestinya narapidana yang telah mendapat pembinaan yang optimal di lembaga pemasyarakatan siap untuk mandiri kelak setelah yang bersangkutan keluar dari lembaga pemasyarakatan. Kemandirian mantan narapidana perlu dimiliki agar di dalam kehidupan masyarakat para mantan narapidana ini dapat berperan serta dalam pembangunan masyarakat, bangsa dan negara sehingga diterima dengan baik oleh masyarakat dan pada akhirnya dapat menghilangkan stigma negatif mantan narapidana.

4) Tidak Tersedianya Sumber Daya Manusia (SDM) yang Profesional dalam Bidang Pendidikan, Agama, Kesehatan, dan Psikologi serta Keterampilan di Lembaga Pemasyarakatan Se-Daerah Istimewa Yogyakarta

Tidak tersedianya sumber daya manusia(SDM)yang profesional dalam bidang pendidikan, agama, kesehatan dan psikologi serta keterampilan di Lembaga Pemasyarakatan se-Daerah Istimewa Yogyakarta mengakibatkan kurang adanya kemandirian dari lembaga pemasyarakatan dalam menjalankan tugas pokok dan fungsi. Tidak tersedianya SDM profesional sesuai bidangnya yang memadai menjadikan pembinaan kepada narapidana di Lembaga Pemasyarakatan se-Daerah Istimewa Yogyakarta kurang maksimal. Hal tersebut memaksa lembaga pemasyarakatan melibatkan SDM yang dimiliki untuk menjalankan tugas pembinaan dengan kemampuan secara amatir. Kondisi demikian memaksa lembaga pemasyarakatan harus kreatif dalam menjalankan tugasnya dengan menjalin kerjasama, baik dengan Pemerintah Daerah, institusi pemerintah maupun Lembaga Swadaya Masyarakat melakukan pembinaan kepada narapidana. Hal inilah yang menimbulkan ketergantungan lembaga pemasyarakatan dengan pihak ketiga, sehingga dapat menimbulkan beban menyangkut biaya penyelenggaraan pembinaan yang konsisten.

5)

Ketidaklayakan Sebagian
dari Kebijakan yang Terkait
dengan Perlindungan HAM
Narapidana di Lembaga Pe-
masyarakatan Se-Daerah Isti-
mewa Yogyakarta

Ketidaklayakan kebijakan yang dimaksud terutama kebijakan akan hak untuk mendapatkan pelayanan kesehatan kepada narapidana yang pada tahun anggaran 2014 dipangkas sehingga mengakibatkan pelayanan kesehatan terganggu terutama apabila menimpa narapidana kasus korupsi yang dijatuhi pidana penjara lebih dari satu tahun dan menderita sakit berkepanjangan. Narapidana yang kondisinya demikian tetap terkena Peraturan Pemerintah Nomor 99 Tahun 2012 yang membatasi hakhaknya dengan persyaratan yang ketat. Hal tersebut sangat membebani petugas lembaga pemasyarakatan, dikarenakan petugas lembaga pemasyarakatan harus melakukan pelayanan dan pengawasan yang ekstra menyangkut rasa kemanusiaan. Suatu persoalan yang dilematis, di satu sisi hak narapidana harus dipenuhi, di sisi lain pelaksanaan pemenuhannya dibatasi, dan pada akhirnya narapidana juga yang menjadi korban. Inilah persoalan nilai kemanusiaan yang 
harus dipertaruhkan dan negara kurang memperhatikannya.

\section{d. Model Kebijakan yang Tepat bagi Perlindungan HAM Narapidana di Lembaga Pemasyarakatan Se- Daerah Istimewa Yogyakarta}

Berdasar pada hasil penelitian yang telah diuraikan di atas dengan berbagai permasalahan yang ditemukan di lapangan, maka model kebijakan perlindungan hak asasi manusia narapidana di lembaga pemasyarakatan se-Daerah Istimewa Yogyakarta yang tepat digunakan adalah model kombinasi antara model elit dan model rasional. Model rasional ini berasal dari pemikiran Herbert Simon yang dikutip Samodera Wijaya, yang menekankan bahwa inti dari perilaku administrasi adalah pada proses pengambilan keputusan secara rasional. Suatu kebijakan negara harus didasarkan pada keputusan yang sudah diperhitungkan rasionalitasnya. ${ }^{19}$ Model ini lebih menekankan pada aspek efisiensi maupun ekonomis. Rasionalitasnya terletak pada perbandingan antara pengorbanan dan hasil yang dicapai. Semakin rendah nilai pengorbanan dan semakin tinggi tingkat pencapaiannya, maka suatu kebijakan dianggap baik. Sepanjang kebijakan yang ditempuh akan memberikan suatu hasil yang baik dengan sumber daya yang paling sedikit, maka kebijakan tersebut layak untuk dilaksanakan.

Hal tersebut di atas dikuatkan dengan data yang telah ditemukan bahwa petugas lembaga pemasyarakatan yang menjalankan tugas harus melaksanakan kebijakan perlindungan hak-hak dasar narapidana yang sudah ada dengan keberanian mengambil keputusan untuk melakukan pelayanan yang terbaik kepada narapidana meski banyak permasalahan yang kurang sesuai dengan kebijakan yang ada, seperti kurangnya anggaran dan fasilitas pembinaan serta pelayanan kesehatan dengan menjalin kerjasama dengan berbagai pihak untuk membantu pembinaan keterampilan, pembinaan mental rohani, pemenuhan bahan baku kegiatan keterampilan dan penyediaan tambahan fasilitas kesehatan. Petugas lembaga pemasyarakatan harus berani mengambil keputusan dalam keterbatasan secara rasional melihat kondisi nyata yang dihadapi untuk memenuhi hak-hak narapidana dengan menekankan baik pada aspek efisiensi maupun ekonomis. Petugas lembaga pemasyarakatan berusaha membantu membekali hasil binaan yang dimiliki, mencoba untuk mendirikan shelter untuk penampungan sementara Narapidana yang baru bebas untuk persiapan ke dunia kerja.

\section{Kesimpulan}

Kebijakan perlindungan HAM bagi narapidana yang dilaksanakan di lembaga pemasyarakatan di Daerah Istimewa Yogyakarta selama ini menggunakan model kombinasi yaitu dengan model kebijakan elit dan model kebijakan rasional. Perlindungan HAM menjadi salah satu sasaran kebijakan Kementerian Hukum dan HAM yang dituangkan dalam berbagai bentuk peraturan perundang-undangan. Kebijakan inilah yang kemudian dilaksanakan oleh Unit Pelaksana Teknis Lembaga Pemasyarakatan se Daerah Istimewa Yogyakarta. Hak nara pidana yang dipenuhi di lembaga pemasyarakatan hanya mengikuti apa yang telah diatur dalam kebijakan-kebijakan pusat, artinya pihak lembaga pemasyarakatan tidak mengupayakan adanya hak-hak yang lain. Di sisi lain, jika ada perubahan kebijakan yang dituangkan dalam peraturan perundangan, peraturan tersebut hanya sekedar tambal sulam. Dalam hal ini kebijakan perlindungan HAM bagi narapidana di 
lembaga pemasyarakatan se-DIY menggunakan Model Kebijakan Elite.

Dalam pelaksanaan/pemenuhannya HAM narapidana di lembaga pemasyarakatan se-DIY pada kenyataannya mengharuskan kreativitas petugas pembina lembaga pemasyarakatan agar dapat berjalan dengan baik, disesuaikan dengan situasi kondisi masing-masing lembaga pemasyarakatan, yang pada kondisi tertentu berbeda dengan peraturan yang sudah ditetapkan oleh Kementerian Hukum dan HAM, namun dapat diterima oleh narapidana. Model penerapan kebijakan ini sesuai dengan Model Kebijakan Rasional.

\section{DAFTAR PUSTAKA}

\section{A. Buku}

Muladi, 1997, Hak Asasi Manusia, Politik dan Sistem Peradilan Pidana, UNDIP, Semarang.

Wijaya, Samodera, 1994, Kebijakan Publik Proses dan Analisis, Intermedia, Jakarta.

\section{B. Artikel Jurnal}

Hartini, Sri, "Perlindungan HAM dalam Praktek Ketatanegaraan di Indonesia dalam Era Globalisasi”, Jurnal Civics, Vol. 2, No. 1, Juni 2005.

\section{Internet}

Afandi, Ahmat Syaiful, "Mantan Napi Lowokwaru Mengaku Mendapat Penyiksaan Saat di Lapas”, http://mediacenter.malangkota.go. id/taykekerasan-pd-napi/8/6-2011, diakses 26 April 2013.

Yudhistira, Andri, "Napi Kasus Terorisme Dianiaya, Ormas Datangi LP Salemba", http:// microsite.metrotvnews.com/metronews/ video/2013/03/15/6/173270/Napi-KasusTerorisme-Dianiaya-Ormas-Datangi-LPSalemba, diakses 26 April 2013.
Prabowo, Dani, "Komnas HAM: Ada Indikasi Pelanggaran HAM dalam Kasus Cebongan", http:/rmol.co/read/2013/04/16/106576/ Siti-Noor-Laila:-Ada-Pelanggaran-HAMDalam-Kasus-Cebongan-, diakses 26 April 2013.

Ditjen Pemasyarakatan Kementerian Hukum dan HAM Republik Indonesia, "Data Jumlah Penghuni Per-Kanwil”, http://smslap. ditjenpas.go.id/public/grl/current/monthly, diakses 1 Mei 2014.

\section{Peraturan Perundang-Undangan}

Undang-Undang Dasar Negara Republik Indonesia Tahun 1945.

Undang-Undang Nomor 12 Tahun 1995 tentang Pemasyarakatan (Lembaran Negara Republik Indonesia Tahun 1995 Nomor 77, Tambahan Lembaran Negara Republik Indonesia Nomor 3614).

Undang-Undang Nomor 39 Tahun 1999 tentang Hak Asasi Manusia (Lembaran Negara Republik Indonesia Tahun 1999 Nomor 165). 